\title{
Factors Associated with Distress Tolerance among Community Dwelling
}

\section{Older Adults}

\author{
Reham Magdy Mohammed Abd EI Salam, Lecturer \\ Gerontological Nursing, Faculty of Nursing, Alexandria University \\ Samia El Husseini Abd El Mageed El Kholy, Lecturer \\ Gerontological Nursing, Faculty of Nursing, Alexandria University
}

\begin{abstract}
Certain people appear to tolerate stress more than others. To shed light on variations in the older adults' tolerance to stress and the reasons behind it, factors which act as moderators should be examined. Objective: Determine factors associated with distress tolerance among community dwelling older adults. Setting: Somoha health insurance outpatient clinics, Alexandria Governorate, Egypt. Subjects: 168 older adults were recruited. Tools: Three tools were used for data collection: 1) Sociodemographic and clinical data structured interview schedule of community dwelling older adults, 2) Factors associated with distress tolerance structured interview schedule of community dwelling older adults, and 3) The Distress Tolerance Scale (DTS). Results: The present study findings showed that the study subjects showed low scores of distress tolerance on the whole which is significantly related to different individual variables. Conclusion: Distress tolerance among the study subjects is significantly associated with personal characteristics, living arrangement, health history, life style patterns, psychological status, and spiritual activities. Recommendations: The gerontological nurses should be oriented to all factors which could affect the older adults' appraisal of possibly stressful situations and their physical, emotional, and behavioral responses to stress and act to control them.
\end{abstract}

Keywords: Distress tolerance; Factors; Older adults; Community dwelling; Gerontological nurse.

\section{Introduction}

Distress tolerance is defined as the capacity to experience and withstand negative emotional state due to stress. Distress may result from mental or physical stressors. It is displayed in an emotional state which characterized by action inclinations to relieve the emotional experience $^{(1)}$. It is the ability of the older adults to cope and live during a crisis, and tolerate short term or long term stressors $^{(2)}$. Distress tolerance should be considered as a continuum where at one end older adults can be very intolerant to distress, and at the other end, older adults can be very tolerant. Sitting at either end of the continuum isn't healthy for older adults. If they are always intolerant in facing all unsatisfying emotions, they may tolerate bad circumstances or bad individuals in their life. If they were tolerant in the extreme, they would never move towards change of unhappy situations in their life that need to be changed $^{(3)}$.

Distress is a natural part of life. Young and old similarly have to face difficult situations and to overcome obstacles. Older adults face a lot of stressors and it was noted that psychological distress is increased after 65 years. Also, elders aged 85 and older are at greater risk to distress and depressive symptoms than other age groups ${ }^{(4)}$ due to multiple stressors such as health related decline and social relationships deterioration. Tolerance to distress may be diminished due to age related changes and poor psychosocial resources ${ }^{(5)}$. Age related changes such as decreased production of neurotransmitters in response to stress among older adults make it harder for them to attain relaxation during distress or to tolerate stressful circumstances. Furthermore, multiple losses such as death 
of spouse or friends, loss of work, loss of adequate income and loss of home environment can reduce older adults' coping abilities to distress. Poor physical performance which induces greater dependency on others may result in further lower levels of distress tolerance ${ }^{(6)}$.

Older adults who are suffering from distress frequently and with low tolerance may have serious physical, emotional, and social problems. Chronic distress disturbs approximately all body systems. It increases the risk of different diseases such as heart diseases and stroke, and speeds up the aging process. Sadness, anxiety, agitation, loneliness and social isolation may be present in the older adults with low distress tolerance. Older adults with distress overload or intolerance may also experience cognitive symptoms such as memory problems, difficult concentration, and poor judgment ${ }^{(7)}$. O'Cleirigh et al. (2007) reported that lower distress tolerance is associated with greater disease symptoms ${ }^{(8)}$. Also, it has been suggested that low distress tolerance may have important role in dysregulated eating disorders ${ }^{(9)}$.

Probably a combination of biological and environmental factors causes some older adults to be more tolerant to emotional distress than others. It is also possible that the older adults' personality and life experiences may shape the way they deal with their emotions in old age. Indeed, if older adults did not learn ways to tolerate emotional distress appropriately, they will maintain using unsuitable methods and will not seek other more helpful ways of dealing with distress ${ }^{(1,4)}$. Moreover, there are several factors controlling the older adults' stress response and distress tolerance. These factors include general individual and environmental characteristics such as older adults' social networks, health behaviors, attitude, and living arrangements. It was reported that having a positive attitude is associated with experiencing greater tolerance to distress ${ }^{(10)}$. Also, it was noticed that older adults with good helpful social networks are more healthy and happy and more able to cope with stress ${ }^{(11)}$.

Gerontological nurses have to encourage older adults to evaluate and to be aware of their levels of distress tolerance through using valid and reliable tools. After that, gerontological nurses should involve the older adults in determining variables which may impede their abilities to face psychological distress. As a result, older adults will be motivated to adopt better lifestyle modifications to enhance their distress tolerance such as eating healthy food, daily exercise, and having adequate period of rest and sleep. Moreover, older adults should be encouraged to be independent as much as possible, to maintain adequate socialization, and to identify negative thinking and replace it with healthy or positive thoughts. Also, training of older adults on different methods of relaxation techniques is the responsibility of the gerontological nurses ${ }^{(12)}$.

Although several researches were done on the different sources of stress among the general population, there are scarce literature which focus on the people' tolerance to distress and its correlates especially among older adults.

\section{Aim of the Study}

The present study aimed to determine factors associated with distress tolerance among community dwelling older adults.

\section{Research Question:}

What are the factors associated with distress tolerance among community dwelling older adults?

\section{Materials and Method}

\section{Materials}

Design: The study followed a descriptive correlational research design.

Setting: The study was carried out at Somoha health insurance outpatient clinics, Alexandria Governorate, Egypt. These 
clinics consist of several specialties such as medical, urology, neurology, and ophthalmology. These clinics work for 6 days $\backslash$ week from Saturday to Thursday from 9 Am to $12 \mathrm{Pm}$.

Subjects: The study included all older adults who were available at the previous setting during the period of data collection and fulfilling the following inclusion criteria:

- Age 60 years and more

- Able to communicate effectively

- Accept to participate in the study Their number amounted to 168 older adults. The sample size was estimated using the EPI info 7.0 program based on these parameters; population size: 300 , possible error $5 \%$, and confidence coefficient 95\%. Accordingly, the minimum estimated sample size was 168.

Tools: Three tools were used in the study to collect the necessary data as follows:

Tool I: Socio-demographic and clinical data structured interview schedule of community dwelling older adults

This tool was developed by the researchers based on review of relevant literature to assess the socio-demographic characteristics of the study subjects such as sex, age, marital status and level of education and clinical data such as selfrating health, health problems.

Tool II: Factors associated with distress tolerance structured interview schedule of community dwelling older adults

This tool was developed by the researchers based on review of relevant literature to assess the factors associated with distress tolerance among older adults. It includes;

- Living arrangement as place of residence, and living condition (either living alone or with family).

- Life style patterns such as sleeping and eating habits.
- Psychological status such as feeling of depression and hopelessness.

- Spiritual activities such as praying and commitment to religious rituals.

Tool III: The Distress Tolerance Scale $\underline{\text { (DTS) }}$

The distress tolerance scale DTS is a 15items self-report tool developed by Simons and Gaher $(2005)^{(1)}$ to assess the individuals' variations in their abilities to tolerate psychological distress. It consists of four subscales as follows; 1 - tolerance: concerned with the ability to tolerate negative emotions, 2- appraisal: concerned with the assessment of the emotional situation as acceptable and evaluation of one's own coping abilities to deal with those negative emotions, 3- absorption: concerned with the level of attention absorbed by the negative emotions and its related interference with functioning, 4- emotional regulation: focus on the action tendencies to either avoid or immediately attenuate the experience. The respondents express how much they disagree or agree with each statement using five Likert scale ranges from (5) strongly disagree to strongly agree (1), the negative items are reversed. High scores indicate high distress tolerance.

\section{Method}

- Permission to carry out the study from the responsible authorities from the Faculty of Nursing, Alexandria University was obtained.

- Permission to collect the required data from the head of the study setting was obtained, after being informed about the purpose of the study, the date and time of data collection.

- Tool I and tool II were developed by the researchers based on review of related literature to assess the sociodemographic and clinical data of the study subjects and factors associated 
with distress tolerance among them respectively.

- Tool III was translated into Arabic language by the researchers. Tool II, and the Arabic version of tool III were tested for content validity by three experts in the study field and the required modifications were done accordingly.

- Tool II, and tool III were tested for reliability. The result of Cronbach's Coefficient alpha was 0.78 for tool II and 0.82 for tool III.

- A pilot study was done on 25older adults selected from the study setting. They were not included in the study sample. The pilot study was done to assess the tools for their applicability and clarity. Essential modifications were done accordingly.

- Older adults who fulfill the inclusion criteria were interviewed individually by the researchers in the waiting area in the outpatient clinics to collect the necessary data after clarification of the study purpose.

\section{Ethical considerations:}

Informed witness consent was obtained from each study subject after clarification of the study purpose. Anonymity and privacy of the study subjects were maintained. Confidentiality of the collected data and the subject's right to withdraw at any time from the study were assured.

\section{Statistical Analysis}

Data collected were analyzed by computer using the Statistical Package for Social Sciences (SPSS) software version 20. Reliability of the tools was determined by Cronbach Coefficient alpha. Data were presented by descriptive statistics in the form of frequencies and percentages for qualitative variables, and arithmetic mean and standard deviation for quantitative variables. Comparison of means was done by Student's t test and One Way Analysis of
Variance (ANOVA). Significant difference was considered if $\mathrm{p} \leq 0.05$.

\section{Results}

Table (1) shows that males constitute $64.9 \%$ of the sample and $35.1 \%$ are females. Their age ranges from 60 to less than 85 years with a mean age of $64.77 \pm 4.82$ and $72.6 \%$ are married. Illiteracy is represented by only $14.3 \%$ of the study subjects, $61.3 \%$ were employee prior to retirement and only $25.0 \%$ are current workers. Inadequate monthly income was reported by $70.2 \%$ of the study subjects.

Table (1) shows that young age group study subjects, $60 \leq 75$ years, have significantly lower distress tolerance regarding the regulation of their emotions during stressful events 7.11 $\pm 2.83, \mathrm{t}=3.77$, $\mathrm{p}<0.001$. Also, illiterate and unskilled workers reported significant lower mean scores of appraisal of one's own abilities to deal with negative emotions such as perceiving having lower abilities than other people, $\mathrm{p}=0.011, \mathrm{p}=0.001$ respectively.

Table (2) indicates that $76.8 \%$ of the study subjects live in urban areas and $84.5 \%$ live with their families. Concerning number of children, $65.5 \%$ of study subjects have more than two children and $56.4 \%, 69.3 \%$ of those who have children reported having unmarried and unemployed children respectively. Absence of family members with physical and/or mental disabilities, and absence of family conflicts were reported by $84.5 \%, 58.3 \%$ of the study subjects respectively. Also, $51.2 \%$ of the study subjects reported that they always suffer from noisy home environment while only $8.9 \%$ reported poor ventilated home environment.

The table also indicates that living in rural area, living alone, living in noisy environment and presence of family conflicts are associated significantly with lower mean scores of distress tolerance $\mathrm{p} \leq 0.05$. While, study subjects who live in well ventilated homes reported higher mean scores of distress tolerance and the 
differences are statistically significant $\mathrm{p} \leq 0.05$.

Table (3) illustrates that more than one half, $56.5 \%$, of the study subjects view their health as good. Diabetes mellitus, hypertension and cardiovascular diseases are the main chronic illnesses that the study subjects suffer from; 84.5\%, 63.7\%, and $29.8 \%$ respectively. Maintaining follow up visits to the health insurance clinics was reported by $83.3 \%$ of the study subjects and $79.8 \%$ are fully independent in their selfcare activities.

The table illustrates that the study subjects who reported poor self-rating health and partial dependency in their self-care activities have lower mean scores of distress tolerance and the differences are statistically significant $\mathrm{p} \leq 0.05$. At the same time, maintaining regular follow up visits to the outpatient clinics is significantly associated with greater distress tolerance, $\mathrm{p} \leq 0.05$.

Table (4) shows the life style patterns of the study subjects where $43.5 \%$ of them take three regular meals per day. Consumption of fresh fruits andlor vegetables for 3 times per week amounted to $55.4 \%$ of the study subjects and $57.1 \%$ reported protein intake 3 times weekly. Oils are reported by $85.7 \%$ of the study subjects to be the fat source used in preparing food.

Regarding the amount of daily fluid intake, $44.6 \%$ of the study subjects consume from 2 to $2.5 \mathrm{~L}$ per day. Only $7.1 \%$ of the study subjects reported no caffeine consumption. Nonsmokers constitute $63.1 \%$ of the study subjects, and those who practice irregular exercises represented $42.3 \%$. Concerning sleep pattern, $15.5 \%$ of the study subjects reported that they always have regular sleep times while, $44.0 \%$ reported that they sometimes sleep according to a fixed schedule. The higher percentage of the study subjects $32.7 \%$ sleep from 5 to 7 hours/day.

The same table indicates that poor eating habits such as consumption of less or more than 3 meals per day and intake of protein, vegetables and/or fruits for only once weekly are associated significantly with lower distress tolerance mean scores and the differences are statistically significant $\mathrm{p} \leq 0.05$. Also, the study subjects who do not consume any caffeinated beverages reported lower mean scores especially in their tolerance to negative emotions $4.92 \pm 3.09$ and the difference is statistically significant $\mathrm{p}=0.012$.

With reference to the sleeping pattern of the study subjects, lower distress tolerance mean scores are reported by those who have unfixed sleep schedule and those who sleep for 10 hours and more. The differences are statistically significant $p \leq 0.05$.

Moreover, a significant association between low distress tolerance mean scores and lack of exercise performance is found, $\mathrm{p}<0.001$.

Table (5) shows that $75.6 \%$ of the study subjects reported loss of significant person during the last year. Feelings of hopelessness and depression are reported by high percentages of the study sample while, only $29.8 \%, 30.4 \%$ did not suffer from these feelings respectively. Moreover, $72.6 \%$ of the study subjects view that their current responsibilities have increased in comparison to the past years. Regarding the type of the study subjects' personalities, $54.8 \%$ of them perceive themselves as somewhat optimistic individuals, while $31.0 \%, 25.6 \%$ of them view themselves as somewhat nervous or very nervous individuals respectively. Also, $62.5 \%$ of the study subjects suffer from current emotional crisis. Concerning exposure to multiple stressors, $64.9 \%, 20.8 \%$ of the study subjects suffer from several stressors either all time or sometimes respectively. These stressors are related to their economic conditions $66.7 \%$, poor physical health $56.9 \%$, family problems $51.4 \%$, or the current political events $37.5 \%$.

The table also shows that the study subjects who did not lose any significant persons within the last year and who did not 
suffer from negative feelings such as depression and hopelessness reported higher mean scores of distress tolerance. While lower mean scores of distress tolerance reported by those who perceive themselves as very nervous or very pessimistic individuals. Also, feeling of increased responsibilities and having current emotional crisis are associated significantly with lower tolerance to psychological distress. The differences are statistically significant $\mathrm{p} \leq 0.05$. In addition, this table shows that the lesser the stressors which the study subjects face, the greater their distress tolerance $\mathrm{p} \leq 0.05$.

Table (6) illustrates the higher percentages of the study subjects $78.6 \%$, $62.5 \%, 59.5 \%$ pray, read or listen to religious subjects, and go to the mosque or church regularly respectively. Also, 69.0\% of them commit to the religious instructions.

The table illustrates that greater distress tolerance mean scores are associated with praying and adherence to religious rituals regularly and the differences are statistically significant, $\mathrm{p} \leq 0.05$. While, lack of attendance to the mosque or church and lack of listening or reading to religious subjects are associated with lower mean scores of distress tolerance, the differences are statistically significant, $\mathrm{p} \leq 0.05$.

Table (7) shows that the study subjects reported low total mean percent score of distress tolerance $43.0 \pm 16.84$ which indicates that the study subjects generally have low distress tolerance. In addition, the table indicates that the study subjects reported low mean percent scores of all distress tolerance subdomains with the lowest mean percent $35.86 \pm 24.57$ related to the emotional regulation subscale which means that the study subjects do great efforts to avoid negative emotions and utilize rapid means of alleviating the negative emotions they experience. Moreover, the least affected domain of distress tolerance is concerned with appraisal of the one's own emotional status as acceptable $46.63 \pm 21.63$.

\section{Discussion}

Old age is associated with many physiological and psychosocial changes that may affect the older adults' responses, appraisals, and tolerance to every day stressors $^{(1,4)}$. The diversity in distress tolerance for similar situations among older adults is still unclear. So, this study aimed to determine the factors associated with distress tolerance among community dwelling older adults.

The present study result shows that low mean percent scores of total and subdomains of distress tolerance were reported by the majority of the study subjects (table 7). This may be because most of the study subjects are males who may have less coping skills than females in addition to poor life resources of the study subjects such as low monthly income. Also, more than one half of study subjects who have children, their children are without work and still un married which result in more problems and strains on their parents. Furthermore, negative feelings were reported by high percentages of the study subjects which impair their tolerance to psychological stress. The present study result is consistent with what is proposed by the psychosocial model of mental health which indicates that psychological health in old age is significantly affected by several external factors such as the social network, income and adverse life situations. Tran et al, 2008 $8^{(13)}$, Caron et al, 2011 ${ }^{(14)}$ revealed that inadequate monthly income was associated with low tolerance to psychological distress. The present study result contradicts those of McDonough 2008, who revealed that females have more psychological distress than males ${ }^{(15)}$. Another study revealed no gender variance in the level of psychological distress ${ }^{(16)}$.

Regarding the present study finding, study subjects reported the lowest mean percent score in emotional regulation subscale of distress tolerance (table 7) which means greater defect in their ability to regulate their negative emotions while 
facing any psychological distress. This means that they prefer to escape from their negative emotions by all means rather than dealing with them. This result may be due to the effect of prolonged exposure to life stressors which gradually diminish their coping reserve and power. So, they sometimes acknowledge this defect and do not try to fight against other problems preferring to escape from them. They also may lose motivations and initiation to handle the negative emotions due to their physiological and pathological health changes. In contrast, Heather et al 2010 reported that older adults show greater emotion regulation. The authors added that older adults accomplish well-being by selecting and optimizing specific emotion regulation processes to compensate for external and internal resource changes ${ }^{(17)}$.

In the present study, young old study subjects showed low distress tolerance mean scores than those who are older (table 1). This can be justified by the fact that despite the older persons may have prolonged and greater exposure to life stressors with negative impacts and consequences, these stressful situations usually carry many benefits for them. For illustration, exposure to stress can teach the older adults different skills which may facilitate their coping with problems later on and do not require new skills or coping abilities. Furthermore, most of older adults in the Egyptian society tend to practice their spiritual activities in a regular way more than before. This can give them greater support to solve their problems and greater satisfaction about their life events. The present finding is congruent with those of Cairney et $\mathrm{al}^{(18)}$ who revealed that advancing age is associated with greater tolerance to psychological distress.

According to the current study finding, poor employment and educational status of the study subjects are significantly associated with negative appraisal of their emotional situation, their abilities and their behaviors during stress (table 1). This result can be clarified by the fact that poor education and employment status may limit the study subjects' chance to experience and to learn different coping skills. Moreover, these study subjects may have low income and poor socioeconomic conditions. These factors may lead them to underestimate their abilities to cope with distress and problems, which will further induce unsuitable behaviors during stressful situations that may cause feeling of shame. This is supported by another study carried out by Kubzansky et al. $2008^{(19)}$ who revealed that lower socioeconomic status is associated with lower levels of distress tolerance.

Concerning living arrangements of the study subjects, the present study result indicates that living in rural area is significantly associated with low distress tolerance (table 2). This may be clarified by certain characteristics of the rural area which may negatively affect the study subjects' tolerance to stress. For illustration, rural area is characterized by little facilities which are necessary for the elders to practice recreational or social activities and there are inadequate, unavailable, and unsatisfying health services. Also, after the age of retirement, there is mainly one job for the older adults to practice with their family members. This job is cultivating the land which needs more economic, physical and mental responsibilities of the older adults. Furthermore, living of the older adults in mainly extended families in the rural area is associated with more engagement in all family problems of children and grandchildren. These factors act as extra stressors facing those who live in rural rather than urban area and limit their tolerance to psychological distress. The present result is congruent with the result of the study done in rural area by Stain et al. $2008^{(20)}$ who revealed that lower distress tolerance was reported due to lower community resources. Another study ${ }^{(21)}$ done in both rural and urban areas, found that psychological distress present in both areas with slightly higher in urban. 
Living alone is found to be significantly associated with lower distress tolerance among the study subjects (table 2). This may be related to the fact that living alone without necessary social support means that one may lose the important and powerful tool in his/her attempt to fight against negative emotions and to solve his/her problems. Moreover, good social support from others motivates and encourages the study subjects during their stressful events. The present result is congruent with those of Zunzunegui et al. $2001^{(22)}$, who suggested that emotional support from children have a vital role in maintaining the physiological and psychological health of older adults. Other studies found that people living alone tend to report a higher level of psychological distress than those living with others ${ }^{(23-25)}$.

With reference to the present study result, family conflicts were significantly associated with lower distress tolerance among the study subjects (table 2). This result may be explained by the fact that continuous family conflicts make the study subjects to be totally absorbed by the family problems which decrease their defense and reserve to deal with other community challenges. Also, presence of family conflicts means that the older adults may lose the needed and necessary social support as mentioned before. This result was supported by what is reported by Tran et al. $2008^{(13)}$ who indicated that problems in family relationships, decrease in families ties, and increased family conflicts were associated with lower tolerance to psychological distress. Also, it was reported that risky families that are characterized by continuous conflicts and aggressive relationships produce disruptions in psychosocial functioning and in stressresponsiveness of their members ${ }^{(26)}$.

Regarding the relation between distress tolerance and the characteristics of the home environment, the current study result indicates a significant association between low distress tolerance among study subjects and living in noisy and poor ventilated homes (table 2). This may be justified by the fact that continuous stimulation of the central nervous system by unwanted external irritant noisy stimuli in the home environment may cause mental exhaustion and loss of concentration. So, the study subjects may become easily provoked and lose control over their reactions toward stress and its associated negative emotions. Also, chronic noisy environment is associated with poor sleep quality and quantity. At the same time, poor ventilated home environment may be associated with unpleasant home odor and unsuitable temperature which act as barriers for effective coping with psychological stress. Study done by Evans et al. 2003 ${ }^{(27)}$ reported that housing with poor quality such as overcrowding, bad odor, and loud external noise reduce tolerance to psychological distress. Also, Weich et al. 2002 ${ }^{(28)}$ revealed that statistically significant associations were found between the prevalence of depression and living in poor housing conditions.

The present finding reveals that, poor self-rating health and poor functional status of the study subjects are significantly related to lower distress tolerance (table 3). This may be interpreted by that, better selfevaluation of health and functional independence are considered among the main variables that support and enable the study subjects to deal with psychological distress without feeling of inadequacy or poor sense of control over their environment. Indeed, they will feel with self-fulfillment and better self-efficacy to manage their problems. The findings of the studies done by Mills et al. 2001 ${ }^{(29)}$ and Schnittker et al. $2005^{(30)}$ showed that lower levels of distress tolerance were found among those who have chronic illnesses and functional limitations.

Having regular follow-up visits to the outpatient clinics is found to be significantly associated with greater distress tolerance among the study subjects (table 3 ). This can 
be interpreted by that regular follow up visits to the outpatient clinics mean that the older adults' chronic diseases and health problems will be kept continuously under control with satisfying level of selfmanagement, and better feeling of wellness and life satisfaction. So, their tolerance to psychological distress will not be affected by their health problems. The current result is in the same line with the study of Ridder et al. $2008^{(31)}$.

With reference to the eating habits of the study subjects, intake of more or less than 3 meals per day, and consumption of protein or fruits and vegetables only one time per week are significantly associated with low distress tolerance among the study subjects (table 4). This can be clarified by the fact that adequate protein, fruits, and vegetables intake (for 3 times per week and more) are necessary to support the immune system through vitamins and needed source of energy in order to face stress and avoid its negative consequences. Moreover, some vitamins such as vitamin $\mathrm{D}$ can help the body to withstand in the face of many stressful or unexpected events through stimulation of serotonin and neurotrophin release, improving metabolic function, and protection of the brain by antioxidant and anti-inflammatory process ${ }^{(32-33)}$. The present study result supports those of other several studies which concluded that low level of vitamins which are found in fruits and vegetables are associated with cognitive and mood disorders and low tolerance to $\operatorname{distress}^{(34-36)}$.

Concerning the present study finding, irregular sleeping times and sleeping for 10 hours and more are negatively associated with lower distress tolerance among the study subjects (table 4). This can be justified by that, poor sleep quality, inadequate or extra hours of sleep and irregular sleeping patterns may result in day time fatigue, low energy level, poor mental concentration and alertness, and greater negative emotions such as feeling of powerlessness and intolerance to distress. In addition, the study subjects may escape from negative emotions by having extra-sleeping hours instead of facing psychological distress. Study done by Steptoe et al. ${ }^{(37)}$, Hamilton et al. $2007^{(38)}$ suggested that positive affect and psychological well-being are directly associated with positive sleep quality. The relations are likely to be bidirectional.

In the current study it was found that study subjects who do not consume any caffeinated beverages show significant lower distress tolerance (table 4). This may be due to the important role of caffeine as a central nervous system stimulator for older adults especially after the normal physiological changes which affect the central nervous system. Furthermore, consumption of the allowable amount of caffeine aids the study subjects to maintain better mental concentration to solve their problems and to tolerate negative emotions associated with it. Several studies concluded that caffeinated beverages have numerous positive effects such as anti-stress and antiinflammatory effects on human health. Also, these studies reported that risk of depression is decreased with increasing consumption of caffeinated coffee $e^{(39-42)}$.

Concerning the performance of physical exercises, study subjects who do not practice exercise reported significant lower distress tolerance (table 4). This result can be interpreted by the negative consequences of inactivity and poor exercise performance. For example, poor systemic circulation, little social interaction, decreased physical resilience and vitality, and negative emotional and cognitive wellbeing are the main outcomes of poor exercise performance. As a result, these study subjects' tolerance to distress will be decreased. The current study result is consistent with what was established by the activity theory about the positive effects of exercises on quality of life. Moreover, other studies revealed that there is a significant association between practice of exercise and distress tolerance changes ${ }^{(43-48)}$. 
The present study finding shows that better psychological status such as having no recent loss of significant persons, no feelings of hopelessness, depression, or increased responsibilities, having no current emotional crisis, and having no much stressors are associated with greater distress tolerance among the study subjects (table 5). In contrast, the study subjects who view themselves as either very nervous or pessimists reported lower distress tolerance (table 5). This result may be due to the fact that psychological status may influence the older adults' appraisals of potentially stressful events. For example, certain personality traits such as hardiness or clamminess allow the older adults to feel control and view their stress effects as less threatening and less complexity than others who are nervous or easily distracted persons. Moreover, optimists are more willing than pessimists to ask for social support, to emphasize on the positive evaluation of the stressors, and to deal with them. Furthermore, presence of stressful events or emotional crisis in a continuous base can diminish the study subjects' coping reserve and tolerance to stress. Findings from numerous studies have shown that older adults with better psychological wellbeing and have greater amount of optimism have better adjustment skills and ability to tolerate psychological distress than others $^{(49-52)}$.

Study subjects who practice their spiritual activities regularly reported higher mean scores of distress tolerance (table 6). This can be illustrated by that, spiritual values may be a source of strength to the older adults and help them to accept suffering and to tolerate distress, make coping easier, and motivate them to act positively. Another study showed that elder's spiritual and religious practices create degrees of calm, comfort, relaxation, and sense of inner peace with self that are significant predictors of psychological wellbeing ${ }^{(53)}$. Furthermore, other studies in 2005, 2008, and 2015 revealed that, there are positive relations between spiritual practices and psychological distress tolerance $^{(54-56)}$.

\section{Conclusion}

Based on the present study results, it can be concluded that distress tolerance among the study subjects is significantly associated with personal characteristics, living arrangement, health history, life style pattern, psychological status, and spiritual activities.

High distress tolerance is significantly associated with regular follow up visits to the outpatient clinics, regular sleeping patterns, having no current emotional crises or loss of significant persons, little exposure to multiple stressors, and absence of negative feeling such as hopelessness and depression. Also, practice of spiritual activities such as praying and commitment to religious rituals regularly are significantly associated with higher tolerance to distress.

Low distress tolerance is significantly associated with younger age group, lower educational level, poor occupational status prior to retirement, living alone, living in rural area, having noisy and poor ventilated home, poor self-rating health, and functional dependency. Irregular meals, poor intake of vegetables, fruits and protein, lack of exercise performance, lack of caffeine consumption, and sleeping for 10 hours and more per day are significantly associated with lower distress tolerance among the study subjects.

Study subjects who are almost nervous and pessimist, who suffer from family conflicts and increased responsibilities, who do not commit to religious rituals and spiritual activities reported significant lower distress tolerance in comparison to the others. 


\section{Recommendations}

Based on the findings of the present study, the following recommendations are suggested:

- Assessment of older adults' responses, appraisal and tolerance to psychological distress should be carried out by the gerontological nurse to facilitate older adults' coping with stressful events.

- Gerontological nurses should strengthen all known variables associated with higher distress tolerance among older adults such as regular health follow up, positive emotional status, and regular practice of spiritual activities.

- All factors that can limit the older adults' abilities to tolerate psychological distress should be identified and controlled by the gerontological nurses to limit their effects such as unhealthy sleeping and eating habits, and functional limitations.
- Developing and conducting an educational program by the gerontological nurses to all care providers and older adults about factors associated with higher and lower distress tolerance and ways to manage andlor control these factors in order to facilitate coping with distress and increase tolerance to it.

\section{The future researches in this field could} include:

- Studies are needed to determine the effect of nursing strategies for enhancing distress tolerance among older adults. 
Table (1): The relation between socio-demographic characteristics and distress tolerance (DT) among the study subjects

\begin{tabular}{|c|c|c|c|c|c|c|c|}
\hline \multirow{2}{*}{$\begin{array}{l}\text { Socio- } \\
\text { demographic } \\
\text { characteristics }\end{array}$} & \multirow{2}{*}{$\begin{array}{l}\text { No= } \\
168\end{array}$} & \multirow[t]{2}{*}{$\%$} & \multirow{2}{*}{$\begin{array}{c}\text { Tolerance } \\
\text { Mean } \pm \text { SD }\end{array}$} & \multirow{2}{*}{$\begin{array}{l}\text { Absorption } \\
\text { Mean } \pm \text { SD }\end{array}$} & \multirow{2}{*}{$\begin{array}{c}\text { Appraisal } \\
\text { Mean } \pm \text { SD }\end{array}$} & \multirow{2}{*}{$\begin{array}{l}\text { Regulation } \\
\text { Mean } \pm \text { SD }\end{array}$} & \multirow{2}{*}{$\begin{array}{c}\text { Total DT } \\
\text { Mean } \pm \text { SD }\end{array}$} \\
\hline & & & & & & & \\
\hline Sex & & & & & & & \\
\hline Male & 109 & 64.9 & $8.17 \pm 3.75$ & $8.73 \pm 3.11$ & $17.47 \pm 5.20$ & $7.19 \pm 2.80$ & $41.57 \pm 10.25$ \\
\hline Female & 59 & 35.1 & $7.39 \pm 3.97$ & $7.80 \pm 3.06$ & $16.68 \pm 5.18$ & $7.51 \pm 3.21$ & $39.37 \pm 9.74$ \\
\hline $\mathbf{t}(\mathbf{p})$ & & & $1.267(0.207)$ & $1.875(0.063)$ & $0.941(0.348)$ & $0.662(0.509)$ & $1.348(0.179)$ \\
\hline $\begin{array}{l}\text { Age ( in years) } \\
60-<75 \text {, Young } \\
\text { old }\end{array}$ & 159 & 94.6 & $7.91 \pm 3.79$ & $8.40 \pm 3.03$ & $17.16 \pm 4.97$ & $7.11 \pm 2.83$ & $40.58 \pm 9.67$ \\
\hline $\begin{array}{l}75 \text { - <85, Middle } \\
\text { old }\end{array}$ & 9 & 5.4 & $7.67 \pm 4.80$ & $8.44 \pm 4.59$ & $17.78 \pm 8.58$ & $10.78 \pm 2.91$ & $44.67 \pm 16.26$ \\
\hline $\mathbf{t}(\mathbf{p})$ & & & $0.186(0.853)$ & $0.027(0.979)$ & $0.215(0.835)$ & $\begin{array}{c}3.775^{*} \\
\left(<0.001^{*}\right)\end{array}$ & $0.747(0.476)$ \\
\hline Marital status & & & & & & & \\
\hline Married & 122 & 72.6 & $8.08 \pm 3.67$ & $8.53 \pm 3.12$ & $17.27 \pm 5.19$ & $7.19 \pm 2.73$ & $41.07 \pm 10.15$ \\
\hline Widow & 41 & 24.4 & $7.44 \pm 4.39$ & $7.90 \pm 3.18$ & $16.90 \pm 5.33$ & $7.66 \pm 3.60$ & $39.90 \pm 10.16$ \\
\hline Divorced & 5 & 3.0 & $7.20 \pm 3.27$ & $9.40 \pm 2.30$ & $17.60 \pm 4.93$ & $7.20 \pm 2.28$ & $41.40 \pm 9.94$ \\
\hline $\mathbf{F}(\mathbf{p})$ & & & $0.513(0.600)$ & $0.889(0.413)$ & $0.092(0.912)$ & $0.390(0.677)$ & $0.213(0.808)$ \\
\hline $\begin{array}{l}\text { Educational level } \\
\text { Illiterate }\end{array}$ & 24 & 14.3 & $7.83 \pm 4.95$ & $7.17 \pm 2.68$ & $14.50 \pm 4.34$ & $7.58 \pm 3.76$ & $37.08 \pm 8.39$ \\
\hline Read \& Write & 20 & 11.9 & $7.15 \pm 3.15$ & $8.30 \pm 1.78$ & $16.95 \pm 3.61$ & $8.40 \pm 2.28$ & $40.80 \pm 6.69$ \\
\hline Primary & 40 & 23.8 & $7.93 \pm 3.81$ & $8.55 \pm 3.77$ & $16.30 \pm 5.88$ & $7.10 \pm 2.96$ & $39.88 \pm 12.77$ \\
\hline Secondary & 33 & 19.6 & $8.36 \pm 3.82$ & $8.91 \pm 2.99$ & $18.73 \pm 5.20$ & $7.0 \pm 2.83$ & $43.0 \pm 9.56$ \\
\hline $\begin{array}{l}\text { University and } \\
\text { above }\end{array}$ & 51 & 30.4 & $7.90 \pm 3.62$ & $8.59 \pm 3.19$ & $18.25 \pm 5.03$ & $7.10 \pm 2.82$ & $41.84 \pm 9.70$ \\
\hline $\mathbf{F}(\mathbf{p})$ & & & $0.308(0.872)$ & $1.241(0.295)$ & $\begin{array}{c}3.354^{*} \\
\left(0.011^{*}\right) \\
\end{array}$ & $0.941(0.442)$ & $1.438(0.224)$ \\
\hline $\begin{array}{l}\text { Occupation prior } \\
\text { to retirement } \\
\text { Employee }\end{array}$ & 103 & 61.3 & $8.02 \pm 3.53$ & $8.69 \pm 3.11$ & $18.26 \pm 4.88$ & $7.19 \pm 2.85$ & $42.17 \pm 9.25$ \\
\hline Housewife & 24 & 14.3 & $7.78 \pm 4.37$ & $7.87 \pm 3.02$ & $16.74 \pm 4.61$ & $7.74 \pm 3.24$ & $40.13 \pm 7.67$ \\
\hline Skilled Worker & 23 & 13.7 & $8.72 \pm 3.95$ & $8.33 \pm 2.91$ & $16.17 \pm 4.22$ & $7.61 \pm 2.91$ & $40.83 \pm 9.54$ \\
\hline $\begin{array}{l}\text { Unskilled } \\
\text { Worker }\end{array}$ & 18 & 10.7 & $6.88 \pm 4.48$ & $7.75 \pm 3.39$ & $13.79 \pm 6.19$ & $7.13 \pm 3.25$ & $35.54 \pm 14.14$ \\
\hline $\mathbf{F}(\mathbf{p})$ & & & $0.885(0.450)$ & $0.866(0.460)$ & $\begin{array}{c}5.611^{*} \\
\left(0.001^{*}\right)\end{array}$ & $0.305(0.821)$ & $\begin{array}{c}2.927^{*} \\
\left(0.035^{*}\right) \\
\end{array}$ \\
\hline Current work & & & & & & & \\
\hline No & 126 & 75.0 & $7.92 \pm 3.92$ & $8.26 \pm 3.14$ & $17.30 \pm 5.35$ & $7.29 \pm 2.94$ & $40.77 \pm 10.46$ \\
\hline Yes & 42 & 25.0 & $7.83 \pm 3.61$ & $8.83 \pm 3.03$ & $16.86 \pm 4.72$ & $7.36 \pm 2.99$ & $40.88 \pm 9.04$ \\
\hline $\mathbf{t}(\mathbf{p})$ & & & $0.127(0.899)$ & $1.029(0.305)$ & $0.479(0.632)$ & $0.136(0.892)$ & $0.062(0.951)$ \\
\hline $\begin{array}{l}\text { Monthly Income } \\
\text { Adequate }\end{array}$ & 50 & 29.8 & $7.84 \pm 3.72$ & $8.58 \pm 2.82$ & $18.04 \pm 4.45$ & $7.76 \pm 2.76$ & $42.02 \pm 8.79$ \\
\hline Inadequate & 118 & 70.2 & $7.92 \pm 3.90$ & $8.33 \pm 3.24$ & $16.83 \pm 5.45$ & $7.19 \pm 3.03$ & $40.28 \pm 10.60$ \\
\hline $\mathbf{t}(\mathbf{p})$ & & & $0.129(0.898)$ & $0.473(0.637)$ & $1.384(0.168)$ & $0.733(0.465)$ & $1.021(0.309)$ \\
\hline
\end{tabular}

$\mathrm{t}, \mathrm{p}: \mathrm{t}$ and $\mathrm{p}$ values for Student t-test. F: $\mathrm{F}$ value for ANOVA test .

$*$ : Statistically significant at $\mathrm{p} \leq 0.05$. Mean \pm SD of age $=64.77 \pm 4.82$ 
Table (2): The relation between living arrangement and distress tolerance among the study subjects

\begin{tabular}{|c|c|c|c|c|c|c|c|}
\hline \multirow{2}{*}{$\begin{array}{l}\text { Living } \\
\text { arrangement }\end{array}$} & \multirow{2}{*}{$\begin{array}{l}\text { No= } \\
168\end{array}$} & \multirow[t]{2}{*}{$\%$} & \multirow{2}{*}{$\begin{array}{c}\text { Tolerance } \\
\text { Mean } \pm \text { SD }\end{array}$} & \multirow{2}{*}{$\begin{array}{l}\text { Absorption } \\
\text { Mean } \pm \text { SD }\end{array}$} & \multirow{2}{*}{$\begin{array}{c}\text { Appraisal } \\
\text { Mean } \pm \text { SD }\end{array}$} & \multirow{2}{*}{$\begin{array}{l}\text { Regulation } \\
\text { Mean } \pm \text { SD }\end{array}$} & \multirow{2}{*}{$\begin{array}{c}\text { Total DT } \\
\text { Mean } \pm \text { SD }\end{array}$} \\
\hline & & & & & & & \\
\hline Place of residence & & & & & & & \\
\hline Urban & 129 & 76.8 & $8.33 \pm 3.96$ & $8.64 \pm 3.23$ & $17.65 \pm 5.40$ & $8.85 \pm 2.66$ & $41.47 \pm 10.46$ \\
\hline Rural & 39 & 23.2 & $6.46 \pm 3.01$ & $7.62 \pm 2.58$ & $15.67 \pm 4.13$ & $6.84 \pm 2.88$ & $38.59 \pm 8.55$ \\
\hline $\mathbf{t}(\mathbf{p})$ & & & $\begin{array}{c}3.147^{*} \\
\left(0.002^{*}\right)\end{array}$ & $\begin{array}{c}2.048^{*} \\
\left(0.044^{*}\right)\end{array}$ & $\begin{array}{c}2.113^{*} \\
\left(0.036^{*}\right)\end{array}$ & $\begin{array}{c}3.883^{*} \\
\left(<0.001^{*}\right)\end{array}$ & $\begin{array}{c}1.565 \\
(0.120)\end{array}$ \\
\hline Living style & & & & & & & \\
\hline With Family & 142 & 84.5 & $8.23 \pm 3.82$ & $8.60 \pm 3.19$ & $17.33 \pm 5.29$ & $7.21 \pm 2.76$ & $41.37 \pm 10.33$ \\
\hline Alone & 26 & 15.5 & $6.12 \pm 3.50$ & $7.35 \pm 2.46$ & $16.42 \pm 4.64$ & $7.81 \pm 3.83$ & $37.69 \pm 8.23$ \\
\hline $\mathbf{t}(\mathbf{p})$ & & & $2.623^{*}\left(0.010^{*}\right)$ & $1.898(0.059)$ & $0.819(0.414)$ & $0.759(0.454)$ & $1.715(0.088)$ \\
\hline Number of Children & & & & & & & \\
\hline None & 5 & 3.0 & $8.80 \pm 4.49$ & $8.60 \pm 1.34$ & $16.60 \pm 4.16$ & $7.0 \pm 3.67$ & $41.0 \pm 5.10$ \\
\hline 1 & 19 & 11.3 & $9.79 \pm 3.78$ & $8.89 \pm 2.31$ & $19.05 \pm 6.13$ & $7.21 \pm 2.44$ & $44.95 \pm 9.30$ \\
\hline 2 & 34 & 20.2 & $7.91 \pm 3.62$ & $8.32 \pm 2.83$ & $17.18 \pm 4.48$ & $7.0 \pm 2.85$ & $40.41 \pm 8.59$ \\
\hline$>2$ & 110 & 65.5 & $7.53 \pm 3.83$ & $8.34 \pm 3.39$ & $16.90 \pm 5.26$ & $7.43 \pm 3.05$ & ${ }^{40} .19 \pm 10.74$ \\
\hline $\mathbf{F}(\mathbf{p})$ & & & $2.009(0.115)$ & $0.186(0.906)$ & $0.950(0.418)$ & $0.206(0.892)$ & $1.223(0.303)$ \\
\hline Married children & $\begin{array}{l}n=16 \\
3\end{array}$ & & & & & & \\
\hline No & 92 & 56.4 & $7.89 \pm 3.93$ & $8.25 \pm 3.17$ & $17.30 \pm 5.35$ & $7.41 \pm 3.07$ & $40.85 \pm 10.06$ \\
\hline Yes & 71 & 43.6 & $7.86 \pm 3.77$ & $8.51 \pm 3.16$ & $17.14 \pm 5.17$ & $7.24 \pm 2.84$ & $40.75 \pm 10.40$ \\
\hline $\mathbf{t}(\mathbf{p})$ & & & $0.047(0.962)$ & $0.515(0.607)$ & $0.186(0.852)$ & $0.364(0.716)$ & $0.059(0.953)$ \\
\hline Employed children & $\begin{array}{l}n=16 \\
3\end{array}$ & & & & & & \\
\hline No & 113 & 69.3 & $8.28 \pm 3.66$ & $8.44 \pm 3.29$ & $16.56 \pm 6.25$ & $7.30 \pm 2.49$ & $40.58 \pm 12.43$ \\
\hline Yes & 50 & 30.7 & $7.69 \pm 3.90$ & $8.38 \pm 3.11$ & $17.50 \pm 4.71$ & $7.32 \pm 3.12$ & $40.88 \pm 9.14$ \\
\hline $\mathbf{t}(\mathbf{p})$ & & & $0.905(0.366)$ & $0.111(0.912)$ & $0.946(0.347)$ & $0.037(0.970)$ & $0.156(0.877)$ \\
\hline $\begin{array}{l}\text { Disable family } \\
\text { members } \\
\text { - No } \\
\text { - Physical and/or } \\
\text { mental disabilities }\end{array}$ & $\begin{array}{c}142 \\
26\end{array}$ & $\begin{array}{l}84.5 \\
15.5\end{array}$ & $\begin{array}{l}7.96 \pm 3.76 \\
7.58 \pm 4.30\end{array}$ & $\begin{array}{l}8.57 \pm 3.08 \\
7.50 \pm 3.22\end{array}$ & $\begin{array}{l}17.36 \pm 5.13 \\
16.27 \pm 5.54\end{array}$ & $\begin{array}{l}7.31 \pm 2.95 \\
7.27 \pm 3.01\end{array}$ & $\begin{array}{r}41.20 \pm 10.15 \\
38.62 \pm 9.74\end{array}$ \\
\hline $\mathbf{t}(\mathbf{p})$ & & & $0.464(0.643)$ & $1.618(0.108)$ & $0.984(0.327)$ & $0.064(0.949)$ & $1.200(0.232)$ \\
\hline Family conflicts & & & & & & & \\
\hline No & 98 & 58.3 & $8.48 \pm 3.78$ & $8.82 \pm 2.99$ & $17.87 \pm 5.30$ & $7.14 \pm 2.74$ & $42.31 \pm 10.03$ \\
\hline Yes & 33 & 19.6 & $6.24 \pm 3.54$ & $6.84 \pm 2.32$ & $15.11 \pm 4.88$ & $7.65 \pm 3.55$ & $35.84 \pm 8.48$ \\
\hline Sometimes & 37 & 22.0 & $8.03 \pm 3.92$ & $8.94 \pm 3.73$ & $17.52 \pm 4.72$ & $7.39 \pm 2.88$ & $41.88 \pm 10.48$ \\
\hline $\mathbf{F}(\mathbf{p})$ & & & $\begin{array}{c}4.793^{*} \\
\left(0.009^{*}\right)\end{array}$ & $\begin{array}{c}6.404^{*} \\
\left(0.002^{*}\right) \\
\end{array}$ & $\begin{array}{l}4.013^{*} \\
\left(0.020^{*}\right)\end{array}$ & $\begin{array}{c}0.412 \\
(0.663) \\
\end{array}$ & $\begin{array}{c}6.092^{*} \\
\left(0.003^{*}\right)\end{array}$ \\
\hline $\begin{array}{l}\text { Noisy home } \\
\text { environment } \\
\text { No }\end{array}$ & 55 & 32.7 & $8.55 \pm 4.40$ & $9.07 \pm 3.84$ & $18.64 \pm 6.10$ & $7.98 \pm 2.84$ & $43.05 \pm 12.39$ \\
\hline Sometimes & 27 & 16.1 & $8.78 \pm 4.06$ & $9.07 \pm 3.26$ & $17.33 \pm 5.92$ & $6.80 \pm 2.98$ & $41.37 \pm 11.99$ \\
\hline Always & 86 & 51.2 & $7.21 \pm 3.26$ & $7.77 \pm 2.37$ & $16.22 \pm 4.04$ & $6.19 \pm 2.76$ & $39.17 \pm 7.27$ \\
\hline $\mathbf{F}(\mathbf{p})$ & & & $\begin{array}{c}2.944 \\
(0.055)\end{array}$ & $\begin{array}{c}3.807^{*} \\
\left(0.024^{*}\right)\end{array}$ & $\begin{array}{c}3.763^{*} \\
\left(0.025^{*}\right)\end{array}$ & $\begin{array}{c}5.240^{*} \\
\left(0.006^{*}\right)\end{array}$ & $2.574(0.079)$ \\
\hline $\begin{array}{l}\text { Ventilated home } \\
\text { environment } \\
\text { No }\end{array}$ & 15 & 8.9 & $6.73 \pm 3.63$ & $7.33 \pm 2.13$ & $16.13 \pm 4.36$ & $8.47 \pm 4.22$ & $38.67 \pm 5.68$ \\
\hline Sometimes & 36 & 21.4 & $6.81 \pm 3.28$ & $7.42 \pm 2.88$ & $15.28 \pm 4.75$ & $7.19 \pm 2.66$ & $36.69 \pm 9.30$ \\
\hline Always & 117 & 9.6 & $8.38 \pm 3.95$ & $8.85 \pm 3.21$ & $17.91 \pm 5.28$ & $7.19 \pm 2.83$ & $42.33 \pm 10.43$ \\
\hline $\mathbf{F}(\mathbf{p})$ & & & $\begin{array}{c}3.171^{*} \\
\left(0.045^{*}\right)\end{array}$ & $\begin{array}{c}4.008^{*} \\
\left(0.020^{*}\right)\end{array}$ & $\begin{array}{c}4.033^{*} \\
\left(0.020^{*}\right)\end{array}$ & $\begin{array}{c}1.286 \\
(0.279)\end{array}$ & $\begin{array}{c}4.872^{*} \\
\left(0.009^{*}\right)\end{array}$ \\
\hline
\end{tabular}


Table (3): The relation between health history and distress tolerance (DT) among the study subjects

\begin{tabular}{|c|c|c|c|c|c|c|c|}
\hline \multirow[t]{2}{*}{$\overline{\text { Health history }}$} & \multirow{2}{*}{$\begin{array}{l}\text { No= } \\
168\end{array}$} & \multirow[t]{2}{*}{$\%$} & \multirow{2}{*}{$\begin{array}{c}\text { Tolerance } \\
\text { Mean } \pm \text { SD }\end{array}$} & \multirow{2}{*}{$\begin{array}{l}\text { Absorption } \\
\text { Mean } \pm \text { SD }\end{array}$} & \multirow{2}{*}{$\begin{array}{c}\text { Appraisal } \\
\text { Mean } \pm \text { SD }\end{array}$} & \multirow{2}{*}{$\begin{array}{l}\text { Regulation } \\
\text { Mean } \pm \text { SD }\end{array}$} & \multirow{2}{*}{$\begin{array}{c}\text { Total DT } \\
\text { Mean } \pm \text { SD }\end{array}$} \\
\hline & & & & & & & \\
\hline Self- rating health & 24 & & $020+383$ & $062+310$ & $2083+520$ & $712+280$ & $4680+1027$ \\
\hline $\begin{array}{l}\text { Very Good } \\
\text { Good }\end{array}$ & $\begin{array}{l}24 \\
95\end{array}$ & $\begin{array}{l}14.3 \\
565\end{array}$ & $\begin{array}{l}9.29 \pm 3.83 \\
7.67+3.58\end{array}$ & $\begin{array}{l}9.63 \pm 3.10 \\
838+315\end{array}$ & $\begin{array}{l}20.83 \pm 5.29 \\
17.14+5.03\end{array}$ & $\begin{array}{l}1.13 \pm 2.80 \\
7.42+2.84\end{array}$ & $\begin{array}{l}46.88 \pm 10.22 \\
4061+10.07\end{array}$ \\
\hline Poor & 49 & 29.2 & $7.65 \pm 4.24$ & $7.86 \pm 2.96$ & $15.51 \pm 4.62$ & $7.16 \pm 3.26$ & $38.18 \pm 8.99$ \\
\hline $\mathbf{F}(\mathbf{p})$ & & & $1.864(0.158)$ & $2.650(0.074)$ & $\begin{array}{c}9.323^{*} \\
\left(<0.001^{*}\right)\end{array}$ & $0.173(0.841)$ & $6.388^{*}\left(0.002^{*}\right)$ \\
\hline Follow up visits & & & & & & & \\
\hline No & 12 & 7.1 & $6.25 \pm 2.99$ & $7.33 \pm 2.64$ & $15.42 \pm 3.34$ & $7.38 \pm 2.96$ & $37.75 \pm 5.94$ \\
\hline Yes & 140 & 83.3 & $8.16 \pm 3.79$ & $8.58 \pm 3.10$ & $17.56 \pm 5.22$ & $8.75 \pm 2.56$ & $41.68 \pm 10.12$ \\
\hline Sometimes & 16 & 9.5 & $6.88 \pm 4.50$ & $7.69 \pm 3.50$ & $15.25 \pm 5.64$ & $5.56 \pm 2.45$ & $35.38 \pm 10.69$ \\
\hline $\mathbf{F}(\mathbf{p})$ & & & $2.019(0.136)$ & $1.356(0.261)$ & $2.212(0.113)$ & $4.457^{*}\left(0.013^{*}\right)$ & $3.485^{*}\left(0.033^{*}\right)$ \\
\hline Self-care ability & & & & & & & \\
\hline Fully independent & 134 & 79.8 & $8.37 \pm 3.79$ & $8.65 \pm 3.09$ & $17.56 \pm 5.16$ & $7.20 \pm 2.74$ & $41.78 \pm 10.18$ \\
\hline $\begin{array}{l}\text { Partially } \\
\text { independent }\end{array}$ & 34 & 20.2 & $6.03 \pm 3.49$ & $7.44 \pm 3.09$ & $15.74 \pm 5.13$ & $7.71 \pm 3.67$ & $36.91 \pm 8.91$ \\
\hline $\mathbf{t}(\mathbf{p})$ & & & $3.433^{*}\left(0.001^{*}\right)$ & $2.037^{*}\left(0.043^{*}\right)$ & $1.843 *(0.067)$ & $0.750(0.458)$ & $2.553^{*}\left(0.012^{*}\right)$ \\
\hline Health problems\# & & & & & & & \\
\hline $\begin{array}{l}\text { Diabetes } \\
\text { mellitus }\end{array}$ & 142 & 84.5 & $7.68 \pm 3.95$ & $8.17 \pm 3.21$ & $16.77 \pm 5.21$ & $7.40 \pm 2.98$ & $40.02 \pm 10.32$ \\
\hline Hypertension & 107 & 63.7 & $7.49 \pm 4.08$ & $8.20 \pm 3.25$ & $17.09 \pm 5.43$ & $7.38 \pm 3.12$ & $40.16 \pm 10.83$ \\
\hline $\begin{array}{l}\text { Cardiovascular } \\
\text { disorders }\end{array}$ & 50 & 29.8 & $6.98 \pm 4.02$ & $7.18 \pm 3.29$ & $16.52 \pm 5.40$ & $7.20 \pm 3.04$ & $37.88 \pm 11.37$ \\
\hline $\begin{array}{l}\text { Musculoskeleta } \\
1 \text { disorders }\end{array}$ & 32 & 19.0 & $8.09 \pm 3.94$ & $7.78 \pm 2.04$ & $15.75 \pm 3.91$ & $7.0 \pm 2.71$ & $38.63 \pm 6.66$ \\
\hline Central nervous & 32 & 19.0 & & & & & \\
\hline $\begin{array}{l}\text { system } \\
\text { disorders }\end{array}$ & & & $7.06 \pm 3.47$ & $8.09 \pm 2.54$ & $17.16 \pm 4.04$ & $7.94 \pm 2.94$ & $40.25 \pm 7.41$ \\
\hline $\begin{array}{l}\text { Gastrointestinal } \\
\text { disorders }\end{array}$ & 22 & 13.1 & $7.56 \pm 3.84$ & $7.89 \pm 2.32$ & $17.11 \pm 3.98$ & $7.44 \pm 4.19$ & $40.0 \pm 5.92$ \\
\hline $\begin{array}{l}\text { Respiratory } \\
\text { disorders }\end{array}$ & 17 & 10.1 & $5.85 \pm 3.21$ & $6.15 \pm 2.23$ & $15.54 \pm 4.25$ & $9.08 \pm 3.84$ & $36.62 \pm 8.05$ \\
\hline Renal disorders & 13 & 7.7 & $7.95 \pm 3.21$ & $8.45 \pm 2.69$ & $17.09 \pm 3.75$ & $8.09 \pm 3.01$ & $41.59 \pm 7.43$ \\
\hline $\begin{array}{l}\text { Ophthalmologi } \\
\text { cal disorders }\end{array}$ & 9 & 5.4 & $8.47 \pm 4.68$ & $7.82 \pm 3.28$ & $16.71 \pm 4.79$ & $7.29 \pm 3.31$ & $40.29 \pm 9.85$ \\
\hline $\mathbf{F}(\mathbf{p})$ & & & $0.742(0.655)$ & $1.239(0.274)$ & $0.373(0.935)$ & $0.818(0.587)$ & $0.586(0.789)$ \\
\hline
\end{tabular}

$t, p: t$ and $p$ values for Student $t$-test

F: $F$ value for ANOVA test

*: Statistically significant at $\mathrm{p} \leq 0.05 \#$ : more than one answer 
Table (4): The relation between life style pattern and distress tolerance (DT) among the study subjects

\begin{tabular}{|c|c|c|c|c|c|c|c|}
\hline \multirow[t]{2}{*}{ Life style patterns } & \multirow{2}{*}{$\begin{array}{l}\text { No= } \\
168\end{array}$} & \multirow[t]{2}{*}{$\%$} & \multirow{2}{*}{$\begin{array}{c}\text { Tolerance } \\
\text { Mean } \pm \text { SD }\end{array}$} & \multirow{2}{*}{$\begin{array}{l}\text { Absorption } \\
\text { Mean } \pm \text { SD }\end{array}$} & \multirow{2}{*}{$\begin{array}{c}\text { Appraisal } \\
\text { Mean } \pm \text { SD }\end{array}$} & \multirow{2}{*}{$\begin{array}{l}\text { Regulation } \\
\text { Mean } \pm \text { SD }\end{array}$} & \multirow{2}{*}{$\begin{array}{c}\text { Total DT } \\
\text { Mean } \pm \text { SD }\end{array}$} \\
\hline & & & & & & & \\
\hline Number of meals per day & & & & & & & \\
\hline Three regular meals & 73 & 43.5 & $8.44 \pm 3.95$ & $8.63 \pm 3.18$ & $18.16 \pm 5.05$ & $8.48 \pm 3.24$ & $41.90 \pm 10.53$ \\
\hline Three irregular meals & 33 & 19.6 & $9.06 \pm 4.49$ & $8.97 \pm 3.88$ & $17.70 \pm 6.56$ & $6.67 \pm 2.54$ & $42.21 \pm 12.97$ \\
\hline $\begin{array}{l}\text { less than or more than } 3 \\
\text { meals }\end{array}$ & 62 & 36.9 & $6.65 \pm 2.94$ & $7.84 \pm 2.48$ & $15.77 \pm 4.22$ & $6.48 \pm 2.55$ & $38.74 \pm 7.30$ \\
\hline $\mathbf{F}(\mathbf{p})$ & & & $5.865^{*}\left(0.003^{*}\right)$ & $1.771(0.173)$ & $3.877^{\prime \prime}\left(0.023^{*}\right)$ & $8.645^{* \prime}\left(<0.001^{*}\right)$ & $2.072(0.129)$ \\
\hline $\begin{array}{l}\text { Intake of fruits and/or } \\
\text { vegetables per week }\end{array}$ & & & & & & & \\
\hline Daily & 27 & 16.0 & $9.22 \pm 4.0$ & $9.44 \pm 3.41$ & $20.78 \pm 4.35$ & $8.42 \pm 3.51$ & $46.11 \pm 10.66$ \\
\hline 3 Times per week & 93 & 55.4 & $8.56 \pm 3.69$ & $8.87 \pm 3.07$ & $17.54 \pm 5.03$ & $6.91 \pm 2.54$ & $41.88 \pm 9.53$ \\
\hline Once per week & 48 & 28.6 & $5.88 \pm 3.29$ & $6.92 \pm 2.53$ & $14.50 \pm 4.56$ & $6.67 \pm 2.73$ & $35.71 \pm 8.78$ \\
\hline $\mathbf{F}(\mathbf{p})$ & & & $\begin{array}{c}10.790^{*} \\
\left(<0.001^{*}\right)\end{array}$ & $\begin{array}{c}8.757^{*} \\
\left(<0.001^{*}\right)\end{array}$ & $\begin{array}{c}15.347^{*} \\
\left(<0.001^{*}\right)\end{array}$ & $\begin{array}{c}5.102^{*} \\
\left(0.007^{*}\right)\end{array}$ & $\begin{array}{c}11.691^{*} \\
\left(<0.001^{*}\right)\end{array}$ \\
\hline Protein intake per week & & & & & & & \\
\hline Daily & 24 & 14.3 & $9.21 \pm 4.23$ & $8.83 \pm 3.66$ & $20.21 \pm 5.31$ & $8.40 \pm 3.34$ & $45.25 \pm 11.82$ \\
\hline 3 Times per week & 96 & 57.1 & $8.58 \pm 3.73$ & $9.03 \pm 3.08$ & $17.78 \pm 5.07$ & $7.0 \pm 3.08$ & $42.23 \pm 9.54$ \\
\hline Once per week & 48 & 28.6 & $5.88 \pm 3.06$ & $6.94 \pm 2.40$ & $14.50 \pm 4.15$ & $6.83 \pm 2.57$ & $35.71 \pm 8.32$ \\
\hline $\mathbf{F}(\mathbf{p})$ & & & $\begin{array}{c}10.717^{*} \\
\left(<0.001^{*}\right)\end{array}$ & $\begin{array}{c}8.123^{*} \\
\left(<0.001^{*}\right)\end{array}$ & $\begin{array}{c}12.675^{*} \\
\left(<0.001^{*}\right) \\
\end{array}$ & $\begin{array}{c}4.857^{*} \\
\left(0.009^{*}\right) \\
\end{array}$ & $\begin{array}{c}10.451^{*} \\
\left(<0.001^{*}\right)\end{array}$ \\
\hline $\begin{array}{l}\text { Source of fat used in food } \\
\text { preparation \# }\end{array}$ & & & & & & & \\
\hline Butter & 69 & 41.1 & $8.36 \pm 3.63$ & $8.99 \pm 2.88$ & $18.39 \pm 5.08$ & $7.07 \pm 3.01$ & $42.81 \pm 8.70$ \\
\hline Margarine & 44 & 26.2 & $7.34 \pm 3.18$ & $8.25 \pm 2.68$ & $16.66 \pm 4.81$ & $7.80 \pm 2.80$ & $40.05 \pm 8.90$ \\
\hline Oils & 144 & 85.7 & $7.97 \pm 3.97$ & $8.35 \pm 3.20$ & $17.19 \pm 5.40$ & $7.15 \pm 2.92$ & $40.67 \pm 10.57$ \\
\hline \begin{tabular}{|r|}
$\mathbf{F}(\mathbf{p})$ \\
\end{tabular} & & & $0.992(0.372)$ & $1.200(0.303)$ & $1.795(0.168)$ & $0.980(0.377)$ & $1.438(0.239)$ \\
\hline Fluid intake per day & & & & & & & \\
\hline$<2$ liters & 69 & 41.1 & $7.32 \pm 3.61$ & $8.51 \pm 3.13$ & $17.52 \pm 5.0$ & $7.16 \pm 3.0$ & $40.51 \pm 9.97$ \\
\hline $2-2.5$ liters & 75 & 44.6 & $8.21 \pm 4.09$ & $8.23 \pm 3.26$ & $16.88 \pm 5.63$ & $7.49 \pm 2.93$ & $40.81 \pm 10.81$ \\
\hline$>2.5$ liters & 24 & 14.3 & $8.58 \pm 3.57$ & $8.67 \pm 2.68$ & $17.21 \pm 4.37$ & $7.13 \pm 2.92$ & $41.58 \pm 8.40$ \\
\hline \begin{tabular}{|c|}
$\mathbf{F}(\mathbf{p})$ \\
\end{tabular} & & & $1.429(0.242)$ & $0.242(0.785)$ & $0.272(0.762)$ & $0.279(0.757)$ & $0.100(0.905)$ \\
\hline $\begin{array}{l}\text { Caffeine consumption/ } \\
\text { day }\end{array}$ & & & & & & & \\
\hline No & 12 & 7.1 & $4.92 \pm 3.09$ & $7.25 \pm 2.93$ & $15.58 \pm 5.58$ & $6.50 \pm 3.15$ & $34.25 \pm 8.75$ \\
\hline 1-2 times & 71 & 42.3 & $7.82 \pm 4.09$ & $8.11 \pm 3.12$ & $17.20 \pm 5.47$ & $7.85 \pm 2.87$ & $40.97 \pm 10.87$ \\
\hline$\geq 3$ times & 85 & 50.6 & $8.39 \pm 3.55$ & $8.81 \pm 3.10$ & $17.41 \pm 4.92$ & $6.96 \pm 2.95$ & $41.58 \pm 9.36$ \\
\hline $\mathbf{F}(\mathbf{p})$ & & & $4.513^{*}\left(0.012^{*}\right)$ & $1.879(0.156)$ & $0.649(0.524)$ & $2.238(0.110)$ & $2.846(0.061)$ \\
\hline Smoking & & & & & & & \\
\hline Current smokers & 27 & 16.1 & $8.41 \pm 3.09$ & $8.56 \pm 2.52$ & $16.41 \pm 3.60$ & $6.67 \pm 2.80$ & $40.04 \pm 5.37$ \\
\hline Pervious smokers & 35 & 20.8 & $8.14 \pm 4.10$ & $8.43 \pm 3.41$ & $17.09 \pm 5.43$ & $7.83 \pm 3.18$ & $41.49 \pm 12.24$ \\
\hline Non-smokers & 106 & 63.1 & $7.69 \pm 3.94$ & $8.36 \pm 3.18$ & $17.42 \pm 5.47$ & $7.29 \pm 2.90$ & $40.76 \pm 10.31$ \\
\hline \begin{tabular}{|c|}
$\mathbf{F}(\mathbf{p})$ \\
\end{tabular} & & & $0.464(0.630)$ & $0.044(0.957)$ & $0.419(0.658)$ & $1.188(0.307)$ & $0.157(0.855)$ \\
\hline Doing of physical exercise & & & & & & & \\
\hline & 46 & 27.4 & $9.35 \pm 3.95$ & $8.93 \pm 3.56$ & $17.46 \pm 5.73$ & $8.41 \pm 2.91$ & $41.74 \pm 11.42$ \\
\hline Irregular & 71 & 42.3 & $8.11 \pm 3.90$ & $8.63 \pm 3.07$ & $17.83 \pm 5.34$ & $7.35 \pm 2.86$ & $41.93 \pm 10.30$ \\
\hline No performance & 51 & 30.4 & $6.29 \pm 3.04$ & $7.61 \pm 2.62$ & $16.06 \pm 4.31$ & $6.0 \pm 2.64$ & $38.37 \pm 8.13$ \\
\hline $\begin{array}{r}\mathbf{F}(\mathbf{p}) \\
\end{array}$ & & & $8.559^{*}\left(<0.001^{*}\right)$ & $2.571(0.080)$ & $1.830(0.164)$ & $8.874^{*}\left(<0.001^{*}\right)$ & $2.144(0.120)$ \\
\hline Fixed sleep times & & & & & & & \\
\hline No & 68 & 40.5 & $8.04 \pm 4.07$ & $8.19 \pm 3.01$ & $16.19 \pm 4.88$ & $6.66 \pm 2.62$ & $40.26 \pm 9.70$ \\
\hline Yes & 26 & 15.5 & $7.08 \pm 3.11$ & $8.54 \pm 2.02$ & $17.73 \pm 3.42$ & $7.84 \pm 3.29$ & $41.08 \pm 5.99$ \\
\hline Sometimes & 74 & 44.0 & $8.05 \pm 3.86$ & $8.55 \pm 3.52$ & $17.92 \pm 5.85$ & $7.73 \pm 2.62$ & $41.19 \pm 11.59$ \\
\hline $\mathbf{F}(\mathbf{p})$ & & & $0.703(0.497)$ & $0.266(0.767)$ & $2.158(0.119)$ & $3.226^{*}\left(0.042^{*}\right)$ & $0.159(0.853)$ \\
\hline Hours of sleep & & & & & & & \\
\hline$<5$ hours & 35 & 20.8 & $7.54 \pm 3.93$ & $8.29 \pm 2.82$ & $18.17 \pm 5.21$ & $6.94 \pm 3.02$ & $40.94 \pm 9.62$ \\
\hline $5-7$ hours & 55 & 32.7 & $8.56 \pm 3.68$ & $9.15 \pm 2.56$ & $16.53 \pm 3.95$ & $7.93 \pm 2.51$ & $42.16 \pm 7.51$ \\
\hline $8-9$ hours & 53 & 31.6 & $8.15 \pm 3.66$ & $8.43 \pm 3.27$ & $18.47 \pm 5.24$ & $7.43 \pm 3.15$ & $42.49 \pm 10.11$ \\
\hline$\geq 10$ hours & 25 & 14.9 & $6.40 \pm 4.19$ & $6.88 \pm 3.83$ & $14.56 \pm 6.42$ & $6.16 \pm 3.08$ & $34.0 \pm 13.10$ \\
\hline $\mathbf{F}(\mathbf{p})$ & & & $2.035(0.111)$ & $3.167^{*}\left(0.026^{*}\right)$ & $4.153^{*}\left(0.007^{*}\right)$ & $2.338(0.075)$ & $4.934^{*}\left(0.003^{*}\right)$ \\
\hline
\end{tabular}

$t, p: t$ and $p$ values for Student $t$-test.

F: F value for ANOVA test

*:Statistically significant at $\mathrm{p} \leq 0.05$.

\#: more than one answer 
Table (5): The relation between psychological status and distress tolerance (DT) among the study subjects

\begin{tabular}{|c|c|c|c|c|c|c|c|}
\hline \multirow[t]{2}{*}{ Psychological status } & \multirow[t]{2}{*}{$\mathrm{No}=168$} & \multirow[t]{2}{*}{$\%$} & \multirow{2}{*}{$\begin{array}{c}\text { Tolerance } \\
\text { Mean } \pm \text { SD }\end{array}$} & \multirow{2}{*}{$\begin{array}{l}\text { Absorption } \\
\text { Mean } \pm \text { SD }\end{array}$} & \multirow{2}{*}{$\begin{array}{c}\text { Appraisal } \\
\text { Mean } \pm \text { SD }\end{array}$} & \multirow{2}{*}{$\begin{array}{l}\text { Regulation } \\
\text { Mean } \pm \text { SD }\end{array}$} & \multirow{2}{*}{$\begin{array}{c}\text { Total DT } \\
\text { Mean } \pm \text { SD }\end{array}$} \\
\hline & & & & & & & \\
\hline $\begin{array}{l}\text { Recent loss of } \\
\text { significant persons }\end{array}$ & & & & & & & \\
\hline No & 41 & 24.4 & $10.05 \pm 3.82$ & $9.78 \pm 3.51$ & $19.59 \pm 4.65$ & $8.69 \pm 3.38$ & $46.05 \pm 10.01$ \\
\hline Yes & 127 & 75.6 & $5.77 \pm 3.34$ & $6.74 \pm 2.57$ & $14.95 \pm 4.32$ & $6.63 \pm 2.93$ & $36.15 \pm 7.89$ \\
\hline $\mathbf{F}(\mathbf{p})$ & & & $\begin{array}{l}14.456^{*} \\
\left(<0.001^{*}\right)\end{array}$ & $\begin{array}{l}10.683^{*} \\
\left(<0.001^{*}\right)\end{array}$ & $\begin{array}{c}8.767^{*} \\
\left(<0.001^{*}\right)\end{array}$ & $\begin{array}{l}6.216 \\
\left(0.002^{*}\right)\end{array}$ & $\begin{array}{l}10.877^{*} \\
\left(<0.001^{*}\right)\end{array}$ \\
\hline Feeling of hopelessness & & & & & & & \\
\hline No & 50 & 29.8 & $10.34 \pm 3.43$ & $10.38 \pm 3.30$ & $21.12 \pm 4.91$ & $6.66 \pm 2.31$ & $48.50 \pm 9.99$ \\
\hline Yes & 25 & 14.8 & $5.96 \pm 4.33$ & $5.68 \pm 2.17$ & $11.52 \pm 3.50$ & $6.80 \pm 3.38$ & $29.96 \pm 8.61$ \\
\hline Sometimes & 93 & 55.4 & $7.11 \pm 3.27$ & $8.08 \pm 2.52$ & $16.60 \pm 3.93$ & $7.78 \pm 3.07$ & $39.57 \pm 6.85$ \\
\hline $\mathbf{F}(\mathbf{p})$ & & & $\begin{array}{l}18.486^{*} \\
\left(<0.001^{*}\right)\end{array}$ & $\begin{array}{l}26.175^{*} \\
\left(<0.001^{*}\right)\end{array}$ & $\begin{array}{c}45.846^{*} \\
\left(<0.001^{*}\right)\end{array}$ & $2.858(0.060)$ & $\begin{array}{c}45.337^{*} \\
\left(<0.001^{*}\right)\end{array}$ \\
\hline Feeling of depression & & & & & & & \\
\hline No & 51 & 30.4 & $9.35 \pm 3.74$ & $9.75 \pm 3.49$ & $20.43 \pm 5.08$ & $7.67 \pm 2.70$ & $47.20 \pm 10.52$ \\
\hline Yes & 25 & 14.8 & $4.96 \pm 3.63$ & $5.56 \pm 2.10$ & $11.72 \pm 3.42$ & $7.48 \pm 3.93$ & $29.72 \pm 8.22$ \\
\hline Sometimes & 92 & 54.8 & $7.89 \pm 3.51$ & $8.43 \pm 2.59$ & $16.88 \pm 4.24$ & $7.05 \pm 2.78$ & $40.26 \pm 7.18$ \\
\hline $\mathbf{F}(\mathbf{p})$ & & & $\begin{array}{l}12.508^{*} \\
\left(<0.001^{*}\right)\end{array}$ & $\begin{array}{l}18.259^{*} \\
\left(<0.001^{*}\right)\end{array}$ & $\begin{array}{c}33.231^{*} \\
\left(<0.001^{*}\right)\end{array}$ & $0.758(0.470)$ & $\begin{array}{c}36.059^{*} \\
\left(<0.001^{*}\right)\end{array}$ \\
\hline $\begin{array}{l}\text { Perceiving of current } \\
\text { responsibilities } \\
\text { Increased }\end{array}$ & 122 & 72.6 & $7.44 \pm 3.76$ & $8.01 \pm 2.87$ & $16.41 \pm 4.58$ & $7.42 \pm 2.96$ & $39.28 \pm 9.02$ \\
\hline Decreased & 23 & 13.7 & $9.96 \pm 3.80$ & $10.57 \pm 3.30$ & $20.43 \pm 5.57$ & $7.74 \pm 3.03$ & $48.70 \pm 10.69$ \\
\hline Did not change & 23 & 13.7 & $8.26 \pm 3.73$ & $8.35 \pm 3.45$ & $18.09 \pm 6.54$ & $6.26 \pm 2.67$ & $40.96 \pm 11.61$ \\
\hline $\mathbf{F}(\mathbf{p})$ & & & $4.447^{* \prime}\left(0.013^{*}\right)$ & $6.983^{*}\left(0.001^{*}\right)$ & $6.631^{* \prime}\left(0.002^{*}\right)$ & $1.798(0.169)$ & $9.244^{*}\left(<0.001^{*}\right)$ \\
\hline $\begin{array}{l}\text { Perceiving oneself as } \\
\text { optimist versus } \\
\text { pessimist } \\
\text { Somewhat optimist } \\
\text { Very optimist } \\
\text { Somewhat pessimist } \\
\text { Very pessimist } \\
\end{array}$ & $\begin{array}{l}92 \\
33 \\
32 \\
11\end{array}$ & $\begin{array}{c}54.8 \\
19.6 \\
19.1 \\
6.5\end{array}$ & $\begin{array}{c}7.68 \pm 3.28 \\
10.97 \pm 3.59 \\
6.28 \pm 3.77 \\
5.18 \pm 3.82\end{array}$ & $\begin{array}{c}8.47 \pm 2.64 \\
10.85 \pm 3.57 \\
6.66 \pm 2.07 \\
5.64 \pm 2.58\end{array}$ & $\begin{array}{c}17.18 \pm 3.60 \\
22.24 \pm 4.86 \\
13.78 \pm 4.95 \\
12.0 \pm 5.46\end{array}$ & $\begin{array}{l}7.77 \pm 3.08 \\
6.42 \pm 2.60 \\
7.41 \pm 2.67 \\
5.73 \pm 2.76\end{array}$ & $\begin{array}{c}41.11 \pm 6.92 \\
50.48 \pm 10.38 \\
34.13 \pm 8.11 \\
28.55 \pm 10.07\end{array}$ \\
\hline $\mathbf{F}(\mathbf{p})$ & & & $\begin{array}{l}13.269^{*} \\
\left(<0.001^{*}\right)\end{array}$ & $\begin{array}{l}16.694^{*} \\
\left(<0.001^{*}\right)\end{array}$ & $\begin{array}{l}27.604^{*} \\
\left(<0.001^{*}\right)\end{array}$ & $2.910^{*}\left(0.036^{*}\right)$ & $\begin{array}{l}31.125^{*} \\
\left(<0.001^{*}\right)\end{array}$ \\
\hline $\begin{array}{l}\text { Perceiving oneself as } \\
\text { nervous versus calm }\end{array}$ & & & & & & & \\
\hline Som & 51 & 30.4 & $8.59 \pm 3.66$ & $9.20 \pm 3.03$ & $17.51 \pm 4.18$ & $7.35 \pm 3.19$ & $42.65 \pm 8.54$ \\
\hline Very & 22 & 13.0 & \pm 3.79 & $10.23 \pm 2.99$ & \pm 4.87 & \pm 2.72 & $49.18 \pm 10.36$ \\
\hline Som & 52 & 31.0 & 2.90 & 7.56 & $=4.13$ & $=2.58$ & $39.08 \pm 7.62$ \\
\hline Very nervous & 42 & 25.6 & $7.14 \pm 4.44$ & $7.56 \pm 3.29$ & $14.77 \pm 5.88$ & $6.93 \pm 3.13$ & $36.40 \pm 11.41$ \\
\hline $\mathbf{F}(\mathbf{p})$ & & & $\begin{array}{c}5.657^{*} \\
\left(0.001^{*}\right)\end{array}$ & $\begin{array}{c}6.531^{*} \\
\left(<0.001^{*}\right)\end{array}$ & $\begin{array}{l}11.890^{*} \\
\left(<0.001^{*}\right)\end{array}$ & $1.403(0.244)$ & $10.331^{*}$ \\
\hline $\begin{array}{l}\text { Current emotional } \\
\text { crisis } \\
\text { No } \\
\text { Yes }\end{array}$ & $\begin{array}{c}105 \\
63\end{array}$ & $\begin{array}{l}62.5 \\
37.5\end{array}$ & $\begin{array}{l}9.17 \pm 3.59 \\
5.78 \pm 3.27\end{array}$ & $\begin{array}{l}9.36 \pm 3.05 \\
6.81 \pm 2.53\end{array}$ & $\begin{array}{l}19.03 \pm 4.63 \\
14.13 \pm 4.63\end{array}$ & $\begin{array}{l}8.16 \pm 3.16 \\
6.79 \pm 2.70\end{array}$ & $\begin{array}{l}44.35 \pm 9.25 \\
34.87 \pm 8.61\end{array}$ \\
\hline $\mathbf{t}(\mathbf{p})$ & & & $6.126^{\prime \prime}\left(<0.001^{\prime \prime}\right)$ & $5.583^{\prime \prime}\left(<0.001^{\prime \prime}\right)$ & $6.645^{\prime \prime}\left(<0.001^{\prime \prime}\right)$ & $2.980 "(0.003 ")$ & $6.596 "(<0.001 ")$ \\
\hline $\begin{array}{l}\text { Exposure to a lot of } \\
\text { stressors }\end{array}$ & & & & & & & \\
\hline No & 24 & 14.3 & $10.92 \pm 3.86$ & $10.54 \pm 3.68$ & $21.46 \pm 5.75$ & $7.51 \pm 3.06$ & $49.79 \pm 11.96$ \\
\hline Yes & 109 & 64.9 & $6.95 \pm 3.74$ & $7.65 \pm 2.86$ & $15.75 \pm 4.67$ & \pm 2.79 & $37.69 \pm 9.01$ \\
\hline Sometimes & 35 & 20.8 & $8.77 \pm 2.80$ & $9.29 \pm 2.58$ & $18.74 \pm 4.33$ & $7.33 \pm 2.96$ & $44.31 \pm 6.74$ \\
\hline $\mathbf{F}(\mathbf{p})$ & & & $\begin{array}{c}13.349 \\
\left(<0.001^{*}\right)\end{array}$ & $\begin{array}{l}11.508^{*} \\
\left(<0.001^{*}\right)\end{array}$ & $\begin{array}{l}16.411^{*} \\
\left(<0.001^{*}\right)\end{array}$ & $0.345(0.709)$ & $\begin{array}{c}20.780^{*} \\
\left(<0.001^{*}\right)\end{array}$ \\
\hline $\begin{array}{l}\text { Types of these } \\
\text { stressors }\end{array}$ & & & & & & & \\
\hline Poor physical health & 82 & 56.9 & $6.50 \pm 3.43$ & $7.45 \pm 2.89$ & $15.52 \pm 5.06$ & $7.52 \pm 3.18$ & $37.0 \pm 9.57$ \\
\hline Economic instability & 96 & 66.7 & $7.57 \pm 3.78$ & $8.09 \pm 3.03$ & $16.25 \pm 4.74$ & $7.56 \pm 3.06$ & $39.48 \pm 9.37$ \\
\hline Family problems & 74 & 51.4 & $7.27 \pm 3.79$ & $7.86 \pm 2.87$ & $16.32 \pm 4.64$ & $7.42 \pm 2.87$ & $38.88 \pm 8.84$ \\
\hline Political events/problems & 54 & 37.5 & $7.89 \pm 3.72$ & $7.70 \pm 2.19$ & $15.39 \pm 3.64$ & $7.89 \pm 3.35$ & $38.87 \pm 6.11$ \\
\hline \begin{tabular}{|c|}
$\mathbf{F}(\mathbf{p})$ \\
\end{tabular} & & & $1.922(0.126)$ & $0.800(0.495)$ & $0.786(0.503)$ & $0.225(0.858)$ & $1.259(0.288)$ \\
\hline
\end{tabular}

$\mathrm{t}, \mathrm{p}: \mathrm{t}$ and $\mathrm{p}$ values for Student $\mathrm{t}$-test.

F: F value for ANOVA test

$*:$ Statistically significant at $\mathrm{p} \leq 0.05$

\#: more than one answer 
Table (6): The relation between spiritual activities and distress tolerance (DT) among the study subjects

\begin{tabular}{|c|c|c|c|c|c|c|c|}
\hline \multirow[t]{2}{*}{ Spiritual activities } & \multirow[t]{2}{*}{ No=168 } & \multirow[t]{2}{*}{$\%$} & \multirow{2}{*}{$\begin{array}{c}\text { Tolerance } \\
\text { Mean } \pm \text { SD } \\
\end{array}$} & \multirow{2}{*}{$\begin{array}{l}\text { Absorption } \\
\text { Mean } \pm \text { SD } \\
\end{array}$} & \multirow{2}{*}{$\begin{array}{c}\text { Appraisal } \\
\text { Mean } \pm \text { SD } \\
\end{array}$} & \multirow{2}{*}{$\begin{array}{l}\text { Regulation } \\
\text { Mean } \pm \text { SD } \\
\end{array}$} & \multirow{2}{*}{$\begin{array}{c}\text { Total DT } \\
\text { Mean } \pm \text { SD } \\
\end{array}$} \\
\hline & & & & & & & \\
\hline Praying & & & & & & & \\
\hline No & 5 & 2.9 & $7.80 \pm 3.81$ & $7.52 \pm 2.90$ & $16.20 \pm 4.97$ & $7.27 \pm 2.90$ & $36.90 \pm 7.51$ \\
\hline Yes & 132 & 78.6 & $9.40 \pm 4.16$ & $9.20 \pm 1.92$ & $17.96 \pm 5.08$ & $8.60 \pm 2.07$ & $43.40 \pm 10.74$ \\
\hline Sometimes & 31 & 18.5 & $8.06 \pm 3.99$ & $8.58 \pm 3.18$ & $14.06 \pm 4.62$ & $7.26 \pm 3.29$ & $41.61 \pm 10.45$ \\
\hline $\mathbf{F}(\mathbf{p})$ & & & $0.450(0.639)$ & $1.652(0.195)$ & $7.746^{*}\left(0.001^{*}\right)$ & $0.495(0.610)$ & $2.969(0.054)$ \\
\hline \begin{tabular}{|l} 
Reading or \\
listening to \\
religious subjects
\end{tabular} & & & & & & & \\
\hline No & 10 & 6.0 & $6.40 \pm 3.86$ & $6.80 \pm 2.97$ & $14.30 \pm 5.08$ & $9.40 \pm 2.91$ & $36.90 \pm 9.18$ \\
\hline Yes & 105 & 62.5 & $7.93 \pm 3.70$ & $8.53 \pm 2.94$ & $17.77 \pm 4.94$ & $7.35 \pm 2.76$ & $41.59 \pm 9.83$ \\
\hline Sometimes & 53 & 31.5 & $8.11 \pm 4.11$ & $8.45 \pm 3.44$ & $16.58 \pm 5.53$ & $6.81 \pm 3.18$ & $39.96 \pm 10.72$ \\
\hline$F(p)$ & & & $0.848(0.430)$ & $1.428(0.243)$ & $2.617(0.076)$ & $3.375^{*}\left(0.037^{*}\right)$ & $1.253(0.288)$ \\
\hline $\begin{array}{l}\text { Attending to } \\
\text { mosque or church }\end{array}$ & & & & & & & \\
\hline No & 27 & 16.1 & $6.30 \pm 3.01$ & $7.52 \pm 3.14$ & $15.96 \pm 5.06$ & $7.48 \pm 2.71$ & $37.26 \pm 9.29$ \\
\hline Yes & 100 & 59.5 & $7.98 \pm 3.95$ & $8.21 \pm 2.91$ & $17.27 \pm 5.17$ & $7.31 \pm 3.01$ & $40.77 \pm 9.98$ \\
\hline Sometimes & 41 & 24.4 & $8.76 \pm 3.79$ & $9.46 \pm 3.38$ & $17.80 \pm 5.33$ & $7.17 \pm 3.0$ & $43.20 \pm 10.45$ \\
\hline $\mathbf{F}(\mathbf{p})$ & & & $3.502^{*}\left(0.032^{*}\right)$ & $3.773^{*}\left(0.025^{*}\right)$ & $1.054(0.351)$ & $0.090(0.914)$ & $2.875(0.059)$ \\
\hline $\begin{array}{l}\text { Commitment to the } \\
\text { religious rules and } \\
\text { rituals }\end{array}$ & & & & & & & \\
\hline No & 34 & 20.3 & $6.76 \pm 3.56$ & $7.62 \pm 2.62$ & $15.29 \pm 3.88$ & $6.85 \pm 2.57$ & $38.44 \pm 7.06$ \\
\hline Yes & 116 & 69.0 & $8.30 \pm 3.89$ & $8.69 \pm 3.19$ & $18.22 \pm 5.29$ & $8.76 \pm 3.62$ & $42.07 \pm 10.77$ \\
\hline Sometimes & 18 & 10.7 & $7.44 \pm 3.75$ & $8.06 \pm 3.37$ & $14.11 \pm 4.68$ & $7.44 \pm 3.07$ & $37.06 \pm 9.19$ \\
\hline $\mathbf{F}(\mathbf{p})$ & & & $2.285(0.105)$ & $1.696(0.187)$ & $8.420^{*}\left(<0.001^{*}\right)$ & $5.872^{*}\left(0.003^{*}\right)$ & $3.159^{*}\left(0.045^{*}\right)$ \\
\hline
\end{tabular}

Table (7): The relation between spiritual activities and distress tolerance (DT) among the study subjects

\begin{tabular}{||l|c|c||}
\hline \hline \multirow{2}{*}{ Distress tolerance } & Mean score & Mean percent \\
\cline { 2 - 3 } & Mean \pm SD & Mean \pm SD \\
\hline Subscales & & \\
1- Tolerance & $7.90 \pm 3.84$ & $40.82 \pm 31.98$ \\
\hline 2- Absorption & $8.40 \pm 3.12$ & $45.04 \pm 25.97$ \\
\hline 3- Appraisal & $17.19 \pm 5.19$ & $46.63 \pm 21.63$ \\
\hline 4- Regulation & $7.30 \pm 2.95$ & $35.86 \pm 24.57$ \\
\hline \multicolumn{1}{|c|}{ Total distress tolerance score } & $\mathbf{4 0 . 8 0 \pm 1 0 . 1 0}$ & $\mathbf{4 3 . 0} \pm \mathbf{1 6 . 8 4}$ \\
\hline
\end{tabular}




\section{References}

1. Simons J, Gaher R. The Distress Tolerance Scale: development and validation of a selfreport measure, motivation and emotion. Psychopathology Behavioral Assessment Journal. 2005; 29(2):83-102.

2. Ridner S.H. Psychological distress: concept analysis. Journal of Advanced Nursing.2004; 45:536-45.

3. Lynch T.R, Mizon G.A, Zvolensky A. B, Vujanovic A.A .Distress over tolerance and distress intolerance: A behavioral perspective, Distress tolerance: Theory, research, and clinical applications. New York: Guilford Press Co. 2011;p.p52-79

4. Sook H.J, Dunkle R.E. Stress and Depression Among the Oldest-Old: A Longitudinal Analysis. Research of Aging Journal. 2009; 31(6): 661-87.

5. Bartels S.J. Improving system of care for older adults with mental illness in the United States. Findings and recommendations for the President's New Freedom Commission on Mental Health. American Journal of Geriatric Psychiatry. 2003; 11(5):486-97.

6. Jorm A.F, Windsor T.D, Dear K.B.G, Anstey K.J, Christensen H, Rodgers B. Age group differences in psychological distress: the role of psychosocial risk factors that vary with age. Psychological Medicine Journal. 2005; 35:1253- 63.

7. Chittleborough C. R, Winefield H, Gill T.K, Koster C, Taylor A.W. Age differences in associations between psychological distress and chronic conditions. International Journal of Public Health.2011; 56 (1):71-80.

8. O'cleirigh $\mathrm{C}$, Ironson $\mathrm{G}$. Does distress tolerance moderate the impact of major life events on psychological variables and behaviors in the management of HIV. Behavioural Therapy Journal 2007; 38(3):314-23.

9. Anestis M, Selby E, Fink E, Joiner T. the multifaceted role of distress tolerance in dysregulating eating behaviors. International journal of eating disorders.2007; 40(8): 718- 26.
10. Préville M, Hébert R, Bravo G, Boyer R. Predisposing and facilitating factors of severe psychological distress among frail elderly. Canadian Journal on Aging. 2002; 21(1):195-204.

11. Krause N. Social support, stress, and wellbeing among older adults. Journal of Gerontolgy 2008; 41(4): S12-1g.

12. Unützer J, Katon W, Callahan C, Williams JW. Collaborative care management of late-life depression in the primary care setting. Journal American of the Medical Association. 2002; 288 (22):2836-45.

13. Tran T.V, Dhooper S.S. Poverty, Chronic Stress, Ethnicity and Psychological Distress Among Elderly Hispanics. Journal of Gerontological Social Work 2008; 27 (4):319.

14. Caron J, Liu A. Factors Associated with Psychological Distress in the Canadian Population: A Comparison of Low-Income and Non Low-Income Sub-Groups. Community Mental Health Journal. 2011; 47(3):318- 30.

15. McDonough $P$, Strohschein L. Age and the Gender Gap in Distress. Journal Women \& Health.2008; 38: 1-20.

16. Thapa S.B, Hauff E. Gender differences in factors associated with psychological distress among immigrants from low- and middle-income countries. Social Psychiatry and Psychiatric Epidemiology Journal.2005; 40:78- 84.

17. Heather L, Gross J.Emotion Regulation in Older Age. Psychological Science Journal.2010; 19 (6): 352- 7.

18. Cairney J, Krause N. The Social Distribution of Psychological Distress and Depression in Older Adults. Journal of aging and health. 2005; 17(6):807- 35 .

19. Kubzansky L.D, Berkman L.F, Seeman T.E. Social Conditions and Distress in Elderly Persons: Findings From the MacArthur Studies of Successful Aging. Gerontology Psychology Society Journal. 2000; 55 (4): 238-46. 
20. Stain H.J, Kelly B, Lewin T.J, Higginbotham N, Beard J.R, Hourihan F. Social networks and mental health among a farming population. Social Psychiatry and Psychiatric Journal.2008;43:843- 58.

21. Havenaar JM, Geerlings MI, Vivian L, Collinson M, Robertson B. Common mental health problems in historically disadvantaged urban and rural communities in South Africa: prevalence and risk factors. Social Psychiatry and Psychiatric Epidemiology Journal. 2008; 43(3):209-15.

22. Zunzunegui M.V, Béland F, Otero A. Support from children, living arrangements, self-rated health and depressive symptoms of older people in Spain. International Epidemiology Journal. 2001; 30 (5): 10909.

23. Paul C, Ayis S, Ebrahim S. Psychological distress, loneliness and disability in old age. Psychology, Health \& Medicine Journal. 2006; 11(2):221- 32.

24. Phongsavan P, Chey T, Bauman A, Brooks R. Social capital, socio-economic status and psychological distress among Australian adults. Social Science \& Medicine Journal. 2006; 63(10):2546- 61.

25. Alpass F.M, Neville S. Loneliness, health and depression in older males. Aging \& Mental Health Journal.2010; 7(3):212-6.

26. Repetti RL, Taylor SE, Seeman TE. Risky families: family social environments and the mental and physical health of offspring. Psychology Journal. 2002; 128(2):330-66.

27. Evans GW, Wells NM, Moch A. Housing and mental health: a review of the evidence and a methodological and conceptual critique. Social Issues Journal. 2003; 59(3):475-500.

28. Weich S, Blanchard M, Prince M, Burton E, Erens B, Sproston K. Mental health and the built environment: cross-sectional survey of individual and contextual risk factors for depression. The British Journal of Psychiatry.2002; 180(5): 428-33.

29. Mills T.L. Comorbid depressive symptomatology: isolating the effects of chronic medical conditions on self-reported depressive symptoms among community- dwelling older adults. Social Science \& Medicine Journal.2001; 53(5):569- 78.

30. Schnittker J. Chronic illness and depressive symptoms in late life. Social Science \& Medicine Journal 2005; 60:13-23.

31. Ridder D, Geenen R, Kuijer R, van H. Psychological adjustment to chronic disease. THE LANCET. 2008; 372 (9634):246- 55.

32. Wilkins $\mathrm{CH}$, Sheline YI, Roe CM, Birge SJ, Morris JC.Vitamin D deficiency is associated with low mood and worse cognitive performance in older adults. American Geriatric Psychiatry Journal. 2006; 14(12):1032-40.

33. Berk M, Sanders KM, Pasco JA, Jacka FN, Williams LJ, Hayles AL. Vitamin D deficiency may play a role in depression. Medical Hypotheses Journal. 2007; 69(6):1316-9.

34. Cherniack P.E, Troen B.R, Florez H.J, Roos B.A, Levis S.Some new food for thought: The role of vitamin $\mathrm{D}$ in the mental health of older adults. Current Psychiatry Journal. 2009; 11:12- 20.

35. Gwon M, Tak YJ, Kim YJ. Is Hypovitaminosis D Associated with Stress Perception in the Elderly? A Nationwide Representative Study in Korea. Nutrients Journal. 2016;8(10):647- 60.

36. Okereke OI, Singh A. The role of vitamin $\mathrm{D}$ in the prevention of late-life depression. Affect Disorder Journal. 2016; 198:1-14.

37. Steptoe A, O'Donnell K, Marmot M, Wardle J. Positive affect, psychological well-being, and good sleep. Psychosomatic Research Journal.2008; 64(4):409- 15.

38. Hamilton N. A, Nelson C. A, Stevens N, Kitzman H. Sleep and psychological wellbeing. Social Indicators Research Journal.2007; 82:147-63.

39. Hintikka J, Tolmunen T, Honkalampi K, Haatainen K, Koivumaa-Honkanen $\mathrm{H}$. Daily tea drinking is associated with a low level of depressive symptoms in the Finnish general population. European epidemiology journal.2005; 20 (4): 359- 63. 
40. Lucas M, Mirzaei F, Pan A, Okereke OI, Willett WC, O'Reilly ÉJ. Coffee, caffeine, and risk of depression among women. Arch Intern Med J. 2011; 171(17):1571-8.

41. Grosso G, Micek A, Castellano S, Pajak A, Galvano F. Coffee, tea, caffeine and risk of depression: A systematic review and doseresponse meta-analysis of observational studies. Molecular Nutrition Food Research Journal. 2016; 60:223-34.

42. Wang L, Shen X, Wu Y, Zhang D. Coffee and caffeine consumption and depression: A meta-analysis of observational studies. Psychiatry Journal. 2016; 50(3):228-42.

43. Martin JC, Wade TJ. The relationship between physical exercise and distress in a national sample of Canadians. Canada Public Health Journal. 2000; 91(4):302-6.

44. Strawbridge WJ, Deleger S, Roberts RE. Physical activity reduces the risk of subsequent depression for older adults. American Epidemiology Journal. 2001; 156(4):328-34.

45. Broose A, Sheets ES, Lett HS. Exercise and the treatment of clinical depression in adults: Recent findings and future directions. Sports Medicine Journal. 2002; 32(12):741-60.

46. Cairney J, Faught BE, Hay JA. Physical activity and psychological distress in older adults. J Phys Act Health. 2005; 2(1):98114.

47. Faulkner G, Carless D. Physical activity and the process of psychiatric rehabilitation: Theoretical and methodological issues. Psychiatric Rehabilitation Journal. 2006; 29:258- 66.

48. Cairney J, Faulkner G, Veldhuizen S, Wade T.J. Changes over Time in Physical Activity and Psychological Distress among Older Adults. Canadian psychiatry journal.2009; 54 (3):89- 164.

49. Scheier MF, Carver CS, Bridges MW. Optimism, pessimism, and psychological well-being. Psychiatric Rehabilitation Journal.2001; 28(4):213- 25.
50. Isaacowitz D. M, Seligman M. E. Is pessimism a risk-factor for depressive mood among community-dwelling older adults?. Behaviour Research Therapy Journal.2001; 39:255-72.

51. Chang E.C. Optimism-Pessimism and Stress Appraisal: Testing a Cognitive Interactive Model of Psychological Adjustment in Adults. Cognitive Therapy Research Journal. 2002; 26(5):675-90.

52. Ferguson SJ, Goodwin AD. Optimism and well-being in older adults: The mediating role of social support and perceived control. International Aging Journal. 2010; 20(4):237-50.

53. Fry P. S. Religious involvement, spirituality and personal meaning for life: Existential predictors of psychological wellbeing in community-residing and institutional care elders. Aging Mental Health Journal. 2010; 4(4):205- 15.

54. Moberg D.O. Research in Spirituality, Religion, and Aging. Gerontological Social Work Journal.2005; 45(2):11-40.

55. Yoon D.P, Othelia E.K. The Impact of Religiousness, Spirituality, and Social Support on Psychological Well-Being Among Older Adults in Rural Areas. Gerontological Social Work Journal. 2008; 48(4):281-89.

56. Noronha K.J.Impact of Religion and Spirituality on Older Adulthood. Religion, Spirituality Aging Journal. 2015; 27:16- 33. 